\title{
Cav2.3 calcium channels control second-phase insulin release
}

\author{
Xingjun Jing, ${ }^{1}$ Dai-Qing Li, ${ }^{1}$ Charlotta S. Olofsson, ${ }^{1}$ Albert Salehi, ${ }^{1}$ Vikas V. Surve, ${ }^{1}$ \\ José Caballero, ${ }^{1}$ Rosita Ivarsson, ${ }^{1}$ Ingmar Lundquist, ${ }^{1}$ Alexey Pereverzev, ${ }^{2}$ \\ Toni Schneider, ${ }^{2}$ Patrik Rorsman, ${ }^{3}$ and Erik Renström ${ }^{1}$
}

\author{
${ }^{1}$ Diabetes Programme at Lund University, Lund, Sweden. ${ }^{2}$ Institute of Neurophysiology and \\ Center of Molecular Medicine Cologne, University of Cologne, Cologne, Germany. ${ }^{3}$ Diabetes Research Laboratories, \\ Oxford Centre for Diabetes, Endocrinology and Metabolism, the Churchill Hospital, Oxford, United Kingdom.
}

\begin{abstract}
Concerted activation of different voltage-gated $\mathrm{Ca}^{2+}$ channel isoforms may determine the kinetics of insulin release from pancreatic islets. Here we have elucidated the role of $\mathrm{R}$-type $\mathrm{Ca}_{\mathrm{v}} 2.3$ channels in that process. A $20 \%$ reduction in glucose-evoked insulin secretion was observed in $\mathrm{Ca}_{v} 2.3$-knockout $\left(\mathrm{Ca}_{V} 2.3^{-/-}\right)$islets, close to the $17 \%$ inhibition by the R-type blocker SNX482 but much less than the $77 \%$ inhibition produced by the L-type $\mathrm{Ca}^{2+}$ channel antagonist isradipine. Dynamic insulin-release measurements revealed that genetic or pharmacological $\mathrm{Ca}_{v} 2.3$ ablation strongly suppressed second-phase secretion, whereas first-phase secretion was unaffected, a result also observed in vivo. Suppression of the second phase coincided with an $18 \%$ reduction in oscillatory $\mathrm{Ca}^{2+}$ signaling and a $25 \%$ reduction in granule recruitment after completion of the initial exocytotic burst in single $\mathrm{Ca}_{V} 2.3^{-/-} \beta$ cells. $\mathrm{Ca}_{\mathrm{v}} 2.3$ ablation also impaired glucose-mediated suppression of glucagon secretion in isolated islets (27\% versus $58 \%$ in WT), an effect associated with coexpression of insulin and glucagon in a fraction of the islet cells in the $\mathrm{Ca}_{V} 2.3^{-/-}$mouse. We propose a specific role for $\mathrm{Ca}_{V} 2.3 \mathrm{Ca}^{2+}$ channels in second-phase insulin release, that of mediating the $\mathrm{Ca}^{2+}$ entry needed for replenishment of the releasable pool of granules as well as islet cell differentiation.
\end{abstract}

\section{Introduction}

Systemic glucose tolerance is orchestrated by the regulated release of insulin and glucagon from the $\beta$ and $\alpha$ cells of the pancreatic islets of Langerhans. The $\alpha$ and $\beta$ cells are electrically excitable and use electrical signals to couple changes in blood glucose concentration to stimulation or inhibition of hormone release. In both cell types, influx of extracellular $\mathrm{Ca}^{2+}$ through voltage-gated $\mathrm{Ca}^{2+}$ channels with resultant elevation of intracellular $\mathrm{Ca}^{2+}$ concentration $\left(\left[\mathrm{Ca}^{2+}\right]_{\mathrm{i}}\right)$ triggers exocytosis of the hormone-containing secretory granules. Like other electrically excitable cells, both $\alpha$ and $\beta$ cells contain several types of voltage-gated $\mathrm{Ca}^{2+}$ channel $(1,2)$. Assigning physiological functions to the respective $\mathrm{Ca}^{2+}$ channels is central to the understanding of electrical and secretory activities in these cells.

Voltage-gated $\mathrm{Ca}^{2+}$ channels are divided into 3 subfamilies: (a) L-type high voltage-activated (HVA) $\mathrm{Ca}^{2+}$ channel family that comprises the $\mathrm{Ca}_{v} 1.1,1.2,1.3$, and 1.4 channels and is inhibited by dihydropyridines (DHPs) (1, 3, 4); (b) non-L-type HVA channels $\mathrm{Ca}_{\mathrm{v}} 2.1$ (P/Q-type), 2.2 (N-type), and 2.3 (R-type) that are sensitive to $\omega$-agatoxin IVA and $\omega$-conotoxin GVIA and SNX482, respectively $(1,4,5)$; and (c) the low voltage-activated (LVA) T-type $\mathrm{Ca}^{2+}$ channel family ( $\mathrm{Ca}_{\mathbf{v}} 3.1,3.2$, and 3.3). The latter subtype differs electrophysiologically from the HVA $\mathrm{Ca}^{2+}$ channels in opening transiently already upon modest depolarization $(6,7)$ and fulfilling important roles in pacemaker cells (8).

Nonstandard abbreviations used: $\left[\mathrm{Ca}^{2+}\right]_{i}$, intracellular $\mathrm{Ca}^{2+}$ concentration; $\mathrm{Ca} \mathrm{V}_{\mathrm{V}} 2.3^{-/-}$, $\mathrm{Ca}_{\mathrm{v}}$ 2.3-knockout; DHP, dihydropyridine; fF, femtofarad(s); HVA, high voltage-activated; $\mathrm{K}_{\mathrm{ATP}}$, ATP-sensitive $\mathrm{K}^{+}$; LVA, low voltage-activated; RRP, readily releasable pool. Conflict of interest: The authors have declared that no conflict of interest exists.

Citation for this article: J. Clin. Invest. 115:146-154 (2005)

doi:10.1172/JCI200522518
The chain of events that couples an elevation in blood glucose to initiation of $\beta$ cell electrical activity is well established and involves facilitated transport of the sugar into the $\beta$ cell and its subsequent metabolic degradation by glycolysis and mitochondrial oxidation, resulting in closure of the ATP-sensitive $\mathrm{K}^{+}$channels $\left(\mathrm{K}_{\mathrm{ATP}}\right.$ channels) and $\beta$ cell depolarization, with resultant activation of voltage-gated $\mathrm{Ca}^{2+}$ channels and regulated insulin exocytosis (9). Glucose-stimulated insulin secretion consists of a rapid first-phase of insulin secretion that lasts for approximately 10 minutes before declining to near-basal levels, followed by less prominent but sustained second-phase insulin secretion that can last for several hours $(10,11)$. The cellular mechanisms underlying biphasic insulin release remain unclear, but consensus exists that an elevation in $\left[\mathrm{Ca}^{2+}\right]_{\mathrm{i}}$ is required for both first- and second-phase insulin secretion (12). Type 2 diabetes is associated with a shift from biphasic to monophasic insulin release (10), and it is therefore important to establish the cell biology of insulin release kinetics.

In mouse pancreatic $\beta$ cells, $50 \%$ of the whole cell $\mathrm{Ca}^{2+}$ current exhibits properties typical for L-type channels, is inhibited by DHP channel blockers such as isradipine or nifedipine, and is activated by BayK8644. The molecular identity of the $\beta$ cell L-type $\mathrm{Ca}^{2+}$ channel involved in insulin secretion has been debated, but recent studies have established that Cav 1.2 or $\alpha 1_{\mathrm{C}}$ channels play a decisive role $(13,14)$.

In mouse $\beta$ cells, there is evidence suggesting that the secretory granules and the L-type $\mathrm{Ca}^{2+}$ channels assemble into a tight functional complex $(13,15-17)$. Thanks to this organization, the $\beta$ cells are capable of exocytosis at rates comparable to those encountered in chromaffin cells, although the $\mathrm{Ca}^{2+}$ channel density is only $5-10 \%$ of that in the latter cell type. This arrangement bears strong resemblance to the tight coupling of P/Q-type $\mathrm{Ca}_{\mathrm{v}} 2.1$ as well as N-type $\mathrm{Ca}_{\mathrm{v}} 2.2$ channels to rapid synaptic transmission $(18,19)$. No such interaction has been demonstrated for the R-type Cav2.3 channels. 

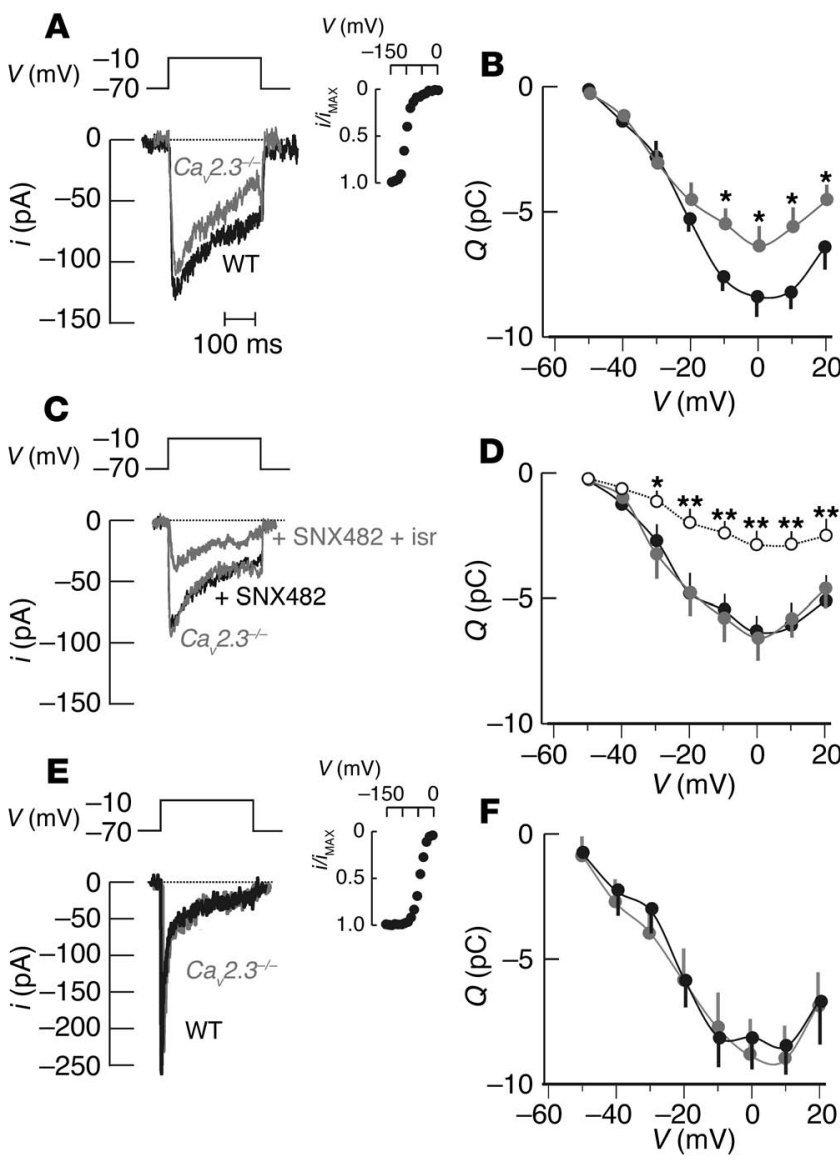

By contrast, recent evidence in neurons suggests that R-type channels are physically detached from the exocytotic machinery (20) and are not involved in rapid neurotransmission in mossy fibers (21).

About one-quarter of the $\beta$ cell whole-cell $\mathrm{Ca}^{2+}$ current is sensitive to the R-type $\mathrm{Ca}^{2+}$ channel blocker SNX482, but the role of R-type $\mathrm{Ca}^{2+}$ channels in insulin secretion remains elusive. A general $\mathrm{Ca}_{v} 2.3-$ knockout $\left(\mathrm{Ca}_{V} 2.3^{---}\right)$mouse has been established. It exhibits a relatively modest neurological phenotype, including altered pain responses (22), impaired spatial memory (23), and enhanced fear reaction (24). Pancreatic islets express the endocrine splice variant of $\mathrm{Ca}_{\mathrm{V}} 2.3$ (25), and previous investigations of glucose homeostasis in $\mathrm{Ca}_{V} 2.3^{-1-}$ mice have demonstrated a slight glucose intolerance and reduced glucoseinduced insulin secretion (26). Here we have extended these initial observations by performing in vivo glucose tolerance tests, dynamic measurements of phasic insulin secretion in situ, static pancreatic hormone-release experiments in isolated islets, as well as single cell recordings of whole-cell $\mathrm{Ca}^{2+}$ currents and exocytosis and ratiometric measurements of the cytoplasmic $\mathrm{Ca}^{2+}$ concentration in WT and $\mathrm{Ca}_{\mathrm{V}} 2.3^{-/-}$islets. We demonstrate that whereas R-type $\mathrm{Ca}^{2+}$ channels play a minor role in rapid insulin release, their significance becomes more apparent during second-phase secretion. These data point to an emerging picture where $\mathrm{Ca}^{2+}$ influx through different $\beta$ cell $\mathrm{Ca}^{2+}$ channels play distinct functional roles.

\section{Results}

Whole cell $\mathrm{Ca}^{2+}$ currents in $\alpha$ and $\beta$ cells from $\mathrm{Ca}_{\mathrm{V}} 2.3^{+/+}$and $\mathrm{Ca}_{\mathrm{V}} 2.3^{-/-}$mice. Integrated $\mathrm{Ca}^{2+}$ current versus voltage $(Q-V)$ relations were measured in dissociated single pancreatic islet cells using the perforated-patch

\section{Figure 1}

Whole-cell $\mathrm{Ca}^{2+}$ currents in islet cells from WT and Cav2.3-1- mice. (A) Whole-cell $\mathrm{Ca}^{2+}$ currents (i) evoked by a $300-\mathrm{ms}$ voltage-clamp depolarization (V) in WT Cav2.3 $3^{+/+}$(black) and $C a_{v} 2.3^{-/-}$(gray) $\beta$ cells. $\beta$ cells were identified by exhibiting half-maximal $\mathrm{Na}^{+}$channel inactivation at membrane potentials $(V)$ lower than $-100 \mathrm{mV}$ (half-maximal inactivation at $-102 \mathrm{mV}$; inset). (B) Average integrated current-voltage $(Q-V)$ relationships. Data are mean values \pm SEM in 10 WT (filled circles) and $10 \mathrm{Ca}_{v} 2.3^{-1-}$ (shaded circles) $\beta$ cells. ${ }^{*} P<0.05$. (C) Wholecell $\mathrm{Ca}^{2+}$ currents were recorded as in $\mathbf{A}$, but using $\mathrm{Ca}_{v} 2.3^{-/-} \beta$ cells. The recordings were made under control conditions (lower gray line) in the presence of R-type $\mathrm{Ca}^{2+}$ channel blocker SNX482 (100 nM; black line) and after addition of L-type $\mathrm{Ca}^{2+}$ channel inhibitor isradipine (isr) (2 $\mu \mathrm{M}$; upper gray line). (D) Average $Q-V$ relationships representing mean values \pm SEM in $4 \mathrm{Ca}_{v} 2.3^{-/-} \beta$ cells under control conditions (shaded circles), in the presence of SNX482 (filled circles), and after addition of isradipine (open circles). ${ }^{*} P<0.05,{ }^{* *} P<0.01$, control versus SNX482 plus isradipine. (E) Whole-cell $\mathrm{Ca}^{2+}$ currents were recorded as in $\mathbf{A}$, but in $\alpha$ cells identified by $\mathrm{Na}^{+}$channel inactivation at membrane potentials greater than $-100 \mathrm{mV}$ (half-maximal inactivation at $-49 \mathrm{mV}$; inset). (F) $Q-V$ relationships in $\alpha$ cells. Data represent average values \pm SEM in 8 WT (filled circles) and $4 \mathrm{Cav}_{2} .3^{-/-}$(shaded circles) $\alpha$ cells. pC, picocoulombs. whole cell configuration. Insulin-releasing $\beta$ cells were identified by the absence of voltage-gated $\mathrm{Na}^{+}$currents at membrane potentials relevant for $\beta$ cell electrical activity, that is, between the $\beta$ cell resting membrane potential $(-70 \mathrm{mV})$ and the peak of the $\beta$ cell action potential $\left(-10 \mathrm{mV}\right.$; Figure $1 \mathrm{~A}$, inset). In $\beta$ cells from $C a_{V} 2 \cdot 3^{-/-}$mice, the integrated $\mathrm{Ca}^{2+}$ currents observed at membrane potentials less than or equal to $-10 \mathrm{mV}$ were reduced compared with WT cells. At $-10 \mathrm{mV}$, the reduction averaged approximately $23 \%(P<0.05$; Figure $1 \mathrm{~B})$. The $\mathrm{C} a_{V} 2.3^{-/-}$mice exhibited a selective loss of a highvoltage $\mathrm{Ca}^{2+}$ current component, and current amplitudes at voltages below $-10 \mathrm{mV}$ were not affected. The R-type $\mathrm{Ca}^{2+}$ channel blocker SNX482 (100 nM) had no effect on voltage-gated $\mathrm{Ca}^{2+}$ currents in $\mathrm{Ca}_{V} 2.3^{-/-}$mice, whereas the L-type inhibitor isradipine $(2 \mu \mathrm{M})$ significantly reduced $\mathrm{Ca}^{2+}$ influx approximately $60 \%$ at potentials greater than or equal to $-30 \mathrm{mV}(P<0.05$; Figure $1, \mathrm{C}$ and $\mathrm{D})$.

Cells exhibiting $\mathrm{Na}^{+}$currents when holding at $-70 \mathrm{mV}$ (Figure 1E, inset) were classified as non- $\beta$ cells and likely represent glucagonreleasing $\alpha$ cells (27). The frequency of $\alpha$ cells was much lower in dispersed islet cells from $\mathrm{Ca}_{V} 2.3^{-/-}$mice than cells made from WT islets. Counting all cells that could be functionally defined as belonging to either group, only approximately $7 \%$ of the $\mathrm{Ca}_{V} 2.3^{-/-}$cells could be classified as $\alpha$ cells versus approximately $27 \%$ of the WT cells. In 4 cells from $C a_{V} 2.3^{-/-}$mice with the electrophysiological properties expected for $\alpha$ cells, the $\mathrm{Ca}^{2+}$ current amplitude was not different from that observed in WT cells (Figure 1, E and F).

Single cell exocytosis in $\mathrm{Ca}_{V} 2.3^{-/-}$and $\mathrm{C} a_{V} 2.3^{+/+}$mice. $\mathrm{Ca}^{2+}$-elicited exocytosis in $\beta$ cells was monitored as increases in whole-cell membrane capacitance and was elicited by trains of 10 500-ms voltage 

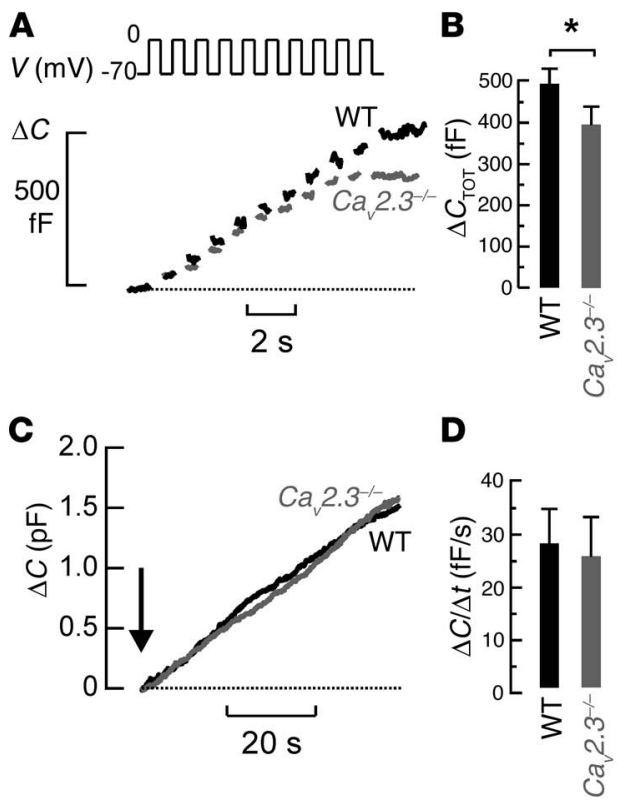
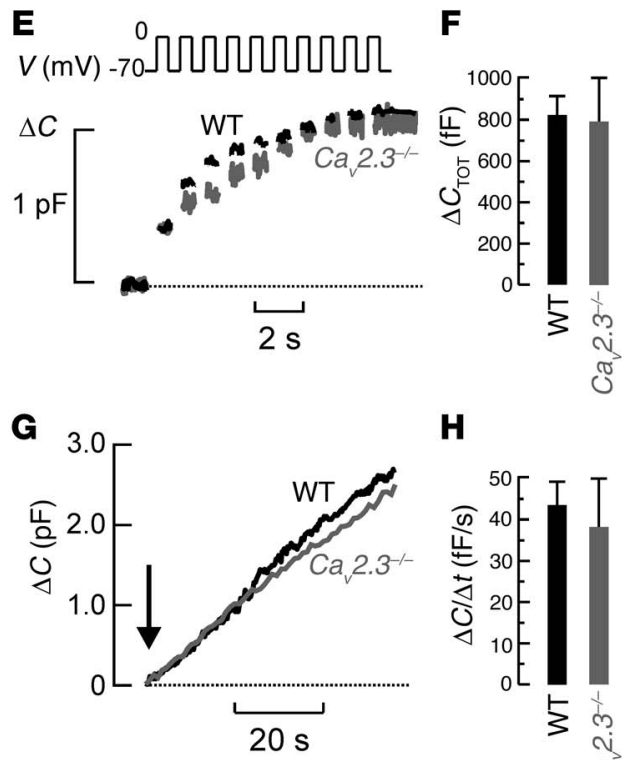

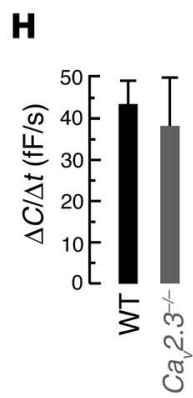

Figure 2

Effects of Cav2.3 ablation on single-cell exocytosis in islet cells. (A) Exocytosis evoked by trains of 10 depolarizations $(V)$ and monitored as increases in cell capacitance $(\Delta C)$ in WT Cav2. $3^{+/+}$(black) and

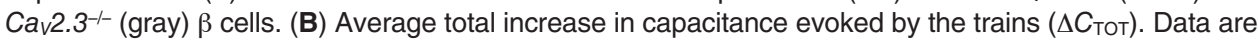
mean values \pm SEM in 6 WT (black bars) and 7 Cav2. $3^{-/-}$(gray bars) $\beta$ cells. ${ }^{*} P<0.05$. (C) $\Delta C$ evoked by intracellular dialysis of a $\mathrm{Ca}^{2+}$-containing patch electrode solution (free $\left[\mathrm{Ca}^{2+}\right]_{\mathrm{i}}$, approximately $1.5 \mu \mathrm{M}$ ) in WT (black) and $\mathrm{Ca}_{v} 2.3^{-/-}$(gray) $\beta$ cells. (D) Average rates of exocytosis $(\Delta \mathrm{C} / \Delta t) \pm \mathrm{SEM}$ evoked by $\mathrm{Ca}^{2+}$ dialysis in $10 \mathrm{WT}$ (black bars) and $10 \mathrm{Ca}_{2} 2.3^{--/}$(gray bars) $\beta$ cells. (E and F) Exocytosis and average $\Delta C$ were recorded as in $\mathbf{A}$ and $\mathbf{B}$, but results are from $\alpha$ cells, and averages represent 5 WT (black) and $3 \mathrm{Ca}_{\mathrm{v}} 2.3^{-/-}$(gray) $\alpha$ cells. ( $\mathbf{G}$ and $\mathbf{H}) \Delta \mathbf{C}$ and average rates of exocytosis were recorded as in $\mathbf{C}$ and $\mathbf{D}$, but the data are from $\alpha$ cells, and mean responses are from 6 WT (black) and 3 Cav2.3-/- (gray) $\alpha$ cells. pF, picofarads.

clamp depolarizations from the holding potential $-70 \mathrm{mV}$ to 0 applied at $1 \mathrm{~Hz}$ (Figure 2, A and B). In $\beta$ cells from $\mathrm{Ca}_{V} 2.3^{-/-}$mice, the increase in cell capacitance during the train averaged $392 \pm 47$ femtofarads (fF) $(n=7)$. The latter value is $21 \%$ less than the exocytotic response evoked by the same stimulus in WT mice $(P<0.05 ; 496 \pm 42 \mathrm{fF} ; n=6)$. Interestingly, the early component of exocytosis (in response to the first depolarization) was not affected and averaged $55 \pm 19 \mathrm{fF}$ and $57 \pm 22 \mathrm{fF}$ in WT and $C a_{V} 2.3^{-/} \beta$ cells, respectively. Instead, selective suppression of the late component of exocytosis was observed. The $23 \%$ reduction of the whole cell $\mathrm{Ca}^{2+}$ current observed in the $\mathrm{Ca}_{V} 2 \cdot 3^{-/-} \beta$ cells corresponded nicely with the overall reduction in exocytosis, suggesting that exocytotic capacity as such was not affected. This idea was reinforced by the observation that exocytotic rates, measured during intracellular dialysis of a $\mathrm{Ca}^{2+}$-containing pipette solution using the standard whole-cell configuration, were identical in $\beta$ cells from both mouse

\section{Figure 3}

$\mathrm{Ca}^{2+}$ homeostasis in WT and $\mathrm{Ca}_{v} 2.3^{-1-}$ islets. $(\mathbf{A})\left[\mathrm{Ca}^{2+}\right]_{\mathrm{i}}$ in an intact WT $\mathrm{Ca}_{\mathrm{v}} 2.3^{+/+}$islet assayed by ratiometric fura- 2 measurements. The islets were stimulated at the time points indicated by the arrows in the continued presence of previously added stimuli. (B) $\left[\mathrm{Ca}^{2+}\right]_{i}$ was determined as in $\mathbf{A}$, but the experiment was performed in an intact $\mathrm{Cav}_{\mathrm{v}} 23^{-/-}$islet. Recordings selected for display are representative of 7 and 9 separate experiments in WT and Cav2.3 $3^{-/}$islets, respectively. Statistical significances are provided in the text. continued presence of glucose elicited a rapid elevation of $\left[\mathrm{Ca}^{2+}\right]_{i}$ but did not result in oscillatory activity. In $\mathrm{Ca}_{V} 2.3^{-1-}$ islets, the glucose-evoked initial peak in $\left[\mathrm{Ca}^{2+}\right]_{\mathrm{i}}$ occurred $227 \pm 15$ seconds $(n=9)$ after elevating the glucose concentration. This initial amplitude was almost unaffected (7\% decrease), but the time-averaged $\left[\mathrm{Ca}^{2+}\right]_{i}$ during the subsequent oscillatory phase was $17 \%$ lower than in WT islets $(P<0.01)$. In addition, the oscillatory activity was $29 \%$ slower
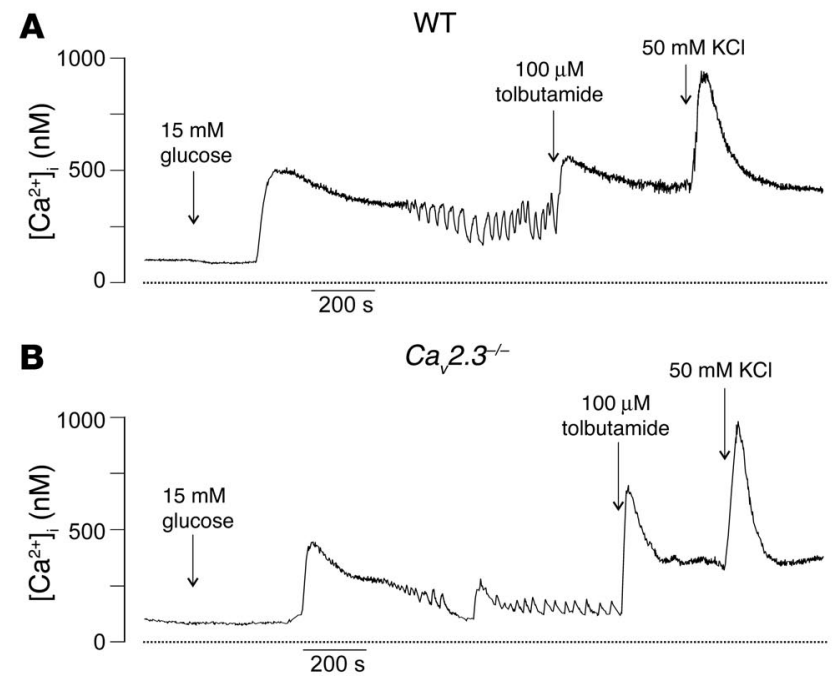


\section{Table 1}

Insulin secretion in response to in vivo glucose challenge in WT

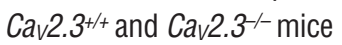

\begin{tabular}{lccc}
\hline & $\begin{array}{c}\text { Time after i.p. } \\
\text { glucose challenge } \\
\text { (min) }\end{array}$ & WT & Cav2.3-- \\
Plasma glucose & 0 & $9.8 \pm 0.6$ & $11.5 \pm 0.8^{\mathrm{A}}$ \\
(mmol/l) & 3 & $16.4 \pm 2.1$ & $18.9 \pm 1.7$ \\
& 8 & $23.0 \pm 2.1$ & $26.5 \pm 2.1^{\mathrm{A}}$ \\
Plasma insulin & 0 & $163.0 \pm 15.5$ & $170.1 \pm 14.8$ \\
(pmol/l) & 3 & $229.4 \pm 29.6$ & $207.5 \pm 11.1$ \\
& 8 & $244.4 \pm 17.8$ & $185.2 \pm 18.5^{\mathrm{A}}$ \\
Plasma glucagon & 0 & $194.0 \pm 15.1$ & $175.7 \pm 6.1$ \\
(ng/l) & 3 & $169.6 \pm 13.2$ & $197.0 \pm 7.7^{\mathrm{A}}$ \\
& 8 & $148.5 \pm 13.5$ & $130.3 \pm 4.9$ \\
\hline
\end{tabular}

Average values for plasma glucose, insulin, and glucagon concentrations \pm SEM immediately before and 3 and 8 minutes after an i.p. glucose challenge ( $2 \mathrm{~g} / \mathrm{kg}$ body weight) in $8 \mathrm{WT}$ and $9 \mathrm{Cav}_{2} 2.3^{-1-}$ mice. Levels of statistical significance are shown only for comparisons between WT and $C a_{v} 2.3^{-1-}$ data. ${ }^{A} P<0.05$.

in the $C a_{V} 2.3^{-/-}$islets $(1.8 \pm 0.1$ versus $2.5 \pm 0.2$ bursts/minute in $\mathrm{C} a_{V} 2.3^{-/-}$and WT islets, respectively; $\left.P<0.01\right)$. By contrast, the peaks in $\left[\mathrm{Ca}^{2+}\right]_{\mathrm{i}}$ induced by depolarization with tolbutamide or high $\mathrm{K}^{+}$ were, if anything, slightly augmented in the $\mathrm{Ca}_{V} 2.3^{-/-}$islets (NS versus control). The finding that no $\left[\mathrm{Ca}^{2+}\right]_{\mathrm{i}}$ oscillations were observed at $5 \mathrm{mM}$ glucose and that elevating the glucose concentration to $15 \mathrm{mM}$ increased $\mathrm{Ca}^{2+}$ signaling suggests that the signal principally reflects the behavior of the pancreatic $\beta$ cells (see ref. 30 ).

In vivo glucose tolerance and pancreatic hormone release in $\mathrm{C}_{V} 2.3^{-/-}$mice. In vivo glucose homeostasis was investigated by intraperitoneal glucose challenges ( $2 \mathrm{~g} / \mathrm{kg}$ body weight; Table 1$)$. Basal (nonfasted) plasma glucose levels averaged $9.8 \pm 0.6 \mathrm{mmol} / 1(n=8)$ in WT $\mathrm{Ca}_{V} 2.3^{+/+}$mice and increased $67 \%$ and $135 \% 3$ and 8 minutes after the glucose load, respectively. In $C a_{V} 2.3^{-/-}$mice, basal glucose levels were elevated by $17 \%$ compared with WT $(P<0.05$ versus WT; $n=9)$, and the plasma glucose concentrations measured 3 and 8 minutes after challenge were also elevated approximately $15 \%(P<0.05$ for values at 8 minutes versus WT). Basal plasma insulin levels did not differ between the $\mathrm{C} a_{V} 2.3^{-/-}$and $C a_{V} 2.3^{+/+}$strains, although the plasma glucose concentration was somewhat higher in the former mice. In WT mice, glucose increased plasma insulin concentrations $43 \%$ and $52 \% 3$ and 8 minutes after the challenge, respectively. In $\mathrm{C} a_{V} 2.3^{-/-}$mice, the glucose-induced increase in circulating insulin was similar to that in WT mice 3 minutes after challenge, but after 8 minutes it was limited to less than $10 \%(P<0.05$ versus WT). These findings reinforce previous observations indicating an impaired glucose tolerance of the $\mathrm{Ca}_{V} 2.3^{-/-}$mice (26).

We also monitored plasma glucagon concentrations during the glucose challenge. Basal glucagon levels in $\mathrm{Ca}_{V} 2.3^{-/-}$mice were modestly decreased (approximately $10 \%$ ) compared with $\mathrm{Ca}_{V} 2.3^{+/+}$littermates. In WT mice, the glucose load reduced circulating glucagon $15 \%$ already at 3 minutes after challenge, and an additional $8 \%$ decrease was observed at 8 minutes. In $C a_{V} 2.3^{-/-}$mice, the inhibition of glucagon release was sluggish. At 3 minutes after challenge, plasma glucagon concentrations actually increased $18 \%(P<0.05$ versus basal; $n=9)$.

Insulin and glucagon release in vitro in pancreatic islets. Pancreatic islets in situ receive extensive neuronal input from parasympathetic nerve endings (31). Since $\mathrm{Ca}_{\mathrm{V}} 2.3 \mathrm{Ca}^{2+}$ channels are also expressed in neuronal tissue, their ablation might affect pancreatic hormone release in vivo by indirect mechanisms and not by directly affecting $\alpha$ and $\beta$ cell function. Insulin and glucagon secretion was therefore also investigated in isolated islets. The first set of experiments investigated the effects of L-type and R-type channel blockers isradipine and SNX482, respectively, in WT $\mathrm{Ca}_{V} 2.3^{+/+}$islets (Table 2). Basal insulin release ( $1 \mathrm{mM}$ glucose) was low and was unaffected by either channel blocker. Elevation of extracellular glucose to $20 \mathrm{mM}$ stimulated insulin release more than 15 -fold. Isradipine $(2 \mu \mathrm{M})$ suppressed glucose-stimulated insulin release 77\%, whereas SNX482 (100 nM) reduced insulin secretion $17 \%$ (Table 2 ). The latter value agrees favorably with the inhibition observed in capacitance measurements (see Figure 2, A and B). Glucagon release was measured under the same conditions. At $1 \mathrm{mM}$ glucose glucagon release was high and remained unchanged by either isradipine or SNX482. Elevating the glucose concentration $(20 \mathrm{mM})$ reduced glucagon secretion $70 \%$ $(P<0.001$; low versus high glucose). At high glucose, blockade of R-type channels by SNX482 failed to affect glucagon release, whereas isradipine stimulated glucagon secretion under the same condition.

We next compared the effects of the $\mathrm{Ca}^{2+}$ channel blockers with the consequences of $\mathrm{Ca}_{\mathrm{V}} 2.3$ gene ablation on pancreatic hormone release (Table 3 ). In WT Ca $2.3^{+/+}$islets, elevating glucose from 1 to $20 \mathrm{mM}$ again stimulated insulin release more than 15 -fold. In $\mathrm{Ca}_{V} 2.3^{-/-}$islets, glucose-stimulated insulin release was reduced approximately $25 \%$ compared with WT. The effects of isradipine on glucose-stimulated insulin release were comparable in WT $(66 \%$ reduction) and in $\mathrm{Ca}_{V} 2.3^{-/-}$islets (68\% suppression). Insulin secretion elicited by stimulation with high extracellular $\mathrm{K}^{+}(50 \mathrm{mM})$ resulted in a $75 \%$ enhancement of release relative to that observed in the presence of glucose alone in WT islets. A similar relative stimulation was observed in $\mathrm{Ca}_{V} 2.3^{-/-}$islets (96\%), but in absolute terms, the response in the latter type of islets was reduced $13 \%$ compared with WT islets. Surprisingly, whereas elevating glucose from 1 to $20 \mathrm{mM}$ suppressed glucagon release $58 \%$ in WT Ca $2.3^{+/+}$islets $(P<0.001$; low versus high glucose), the inhibitory action of the sugar was severely impaired in the $\mathrm{Ca}_{V} 2.3^{-/-}$islets and amounted to a mere $27 \%(P<0.01$ versus WT). Isradipine exerted divergent actions in WT and $\mathrm{Ca}_{V} 2.3^{--}$islets. As discussed above, in WT islets the

\section{Table 2}

Effects of $\mathrm{Ca}^{2+}$ channel inhibitors on in vitro insulin and glucagon release in WT Cav2.3 $3^{+/+}$islets

\begin{tabular}{|c|c|c|}
\hline Condition & $\begin{array}{l}\text { Insulin secretion } \\
\text { (ng/islet/h) }\end{array}$ & $\begin{array}{c}\text { Glucagon secretion } \\
(\mathrm{pg} / \mathrm{islet} / \mathrm{h})\end{array}$ \\
\hline $1 \mathrm{mM}$ glucose & $0.2 \pm 0.03$ & $38.4 \pm 3.0$ \\
\hline $\begin{array}{c}1 \mathrm{mM} \text { glucose + } \\
2 \mu \mathrm{M} \text { isradipine }\end{array}$ & $0.2 \pm 0.05$ & $36.7 \pm 6.1$ \\
\hline $\begin{array}{c}1 \text { mM glucose + } \\
100 \text { nM SNX482 }\end{array}$ & $0.3 \pm 0.03$ & $38.5 \pm 4.5$ \\
\hline $20 \mathrm{mM}$ glucose & $2.6 \pm 0.2^{\mathrm{A}}$ & $12.8 \pm 4.7^{\mathrm{A}}$ \\
\hline $\begin{array}{l}20 \mathrm{mM} \text { glucose }+ \\
2 \mu \mathrm{M} \text { isradipine }\end{array}$ & $0.7 \pm 0.08^{A, B}$ & $22.8 \pm 2.1^{\mathrm{A}, \mathrm{C}}$ \\
\hline $\begin{array}{l}20 \text { mM glucose + } \\
100 \text { nM SNX482 }\end{array}$ & $2.3 \pm 0.2^{\mathrm{A}}$ & $16.2 \pm 4.1^{\mathrm{D}}$ \\
\hline \multicolumn{3}{|c|}{$\begin{array}{l}\text { Average values for insulin and glucagon release } \pm \mathrm{SEM} \text { measured in } \\
60 \text {-minute batch incubations of } 10 \text { islets from WT Cav2. } 3^{+/+} \text {mice under } \\
\text { conditions as indicated. Data are from } 10 \text { independent experiments. } \\
\text { AP } P<0.001, \mathrm{D} P<0.05 \text { versus the same condition in } 1 \mathrm{mM} \text { glucose; } \\
\mathrm{B} P<0.001, \mathrm{C} P<0.05 \text { versus } 20 \mathrm{mM} \text { glucose alone. }\end{array}$} \\
\hline
\end{tabular}


Table 3

Effects of Cav2.3 ablation on in vitro insulin and glucagon release

\begin{tabular}{|c|c|c|c|c|}
\hline & \multicolumn{2}{|c|}{$\begin{array}{l}\text { Insulin release } \\
\text { (ng/islet/h) }\end{array}$} & \multicolumn{2}{|c|}{$\begin{array}{c}\text { Glucagon release } \\
(\mathrm{pg} / \mathrm{islet} / \mathrm{h})\end{array}$} \\
\hline & WT & Cav2.3-/- & WT & Cav2.3-l- \\
\hline $1 \mathrm{mM}$ glucose & $0.2 \pm 0.02$ & $0.4 \pm 0.05$ & $39.8 \pm 1.3$ & $40.9 \pm 1.8$ \\
\hline 20 mM glucose & $3.1 \pm 0.3$ & $2.4 \pm 0.1^{A}$ & $16.9 \pm 1.5$ & $29.8 \pm 3.5^{A}$ \\
\hline $\begin{array}{l}20 \mathrm{mM} \text { glucose + } \\
2 \mu \mathrm{M} \text { isradipine }\end{array}$ & $0.8 \pm 0.09 \mathrm{~B}$ & $1.1 \pm 0.1^{\mathrm{B}}$ & $25.7 \pm 1.9^{c}$ & $20.3 \pm 2.3^{D}$ \\
\hline $\begin{array}{c}20 \text { mM glucose } \\
+50 \mathrm{mM} \mathrm{K}^{+}\end{array}$ & $5.4 \pm 0.2^{\mathrm{B}}$ & $4.7 \pm 0.3^{B, D}$ & $71.7 \pm 6.5^{\mathrm{E}}$ & $94.8 \pm 10.6^{A, B}$ \\
\hline
\end{tabular}

Average values for insulin and glucagon release measured in 60-minute batch

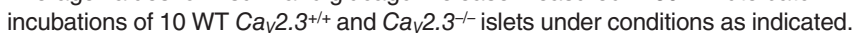
Data represent means \pm SEM of 18 experiments in each group. ${ }^{A} P<0.01$ $\mathrm{E} P<0.05$ for comparisons between WT and $C a_{V} 2.3^{-1-}$; $\mathrm{B} P<0.001, \mathrm{C} P<0.01$, $\mathrm{D} P<0.05$ versus results obtained in $20 \mathrm{mM}$ glucose alone.

L-type $\mathrm{Ca}^{2+}$ channel antagonist stimulated glucagon release $52 \%$ when applied in the presence of $20 \mathrm{mM}$ glucose. By contrast, isradipine reduced glucagon secretion in $\mathrm{Ca}_{V} 2.3^{-/}$islets $32 \%$ under high-glucose conditions. Increasing extracellular $\mathrm{K}^{+}$enhanced glucagon secretion massively, approximately $320 \%$ in WT and $220 \%$ in $\mathrm{Ca}_{V} 2.3^{-/-}$islets.

Phasic insulin release measured by in situ pancreatic perfusion. To assess the role of $\mathrm{Ca}_{2} 2.3$ in dynamic insulin release, we performed in situ pancreatic perfusions with fractionated sampling. When WT $\mathrm{Ca}_{V} 2.3^{+/+}$pancreata were perfused (Figure $4 \mathrm{~A}$ ) with a low-glucose solution $(3.3 \mathrm{mM})$, insulin release was barely detectable. After increasing the glucose concentration to $16.7 \mathrm{mM}$ (at $t=11$ minutes), first-phase insulin release was initiated with a 2-minute delay. The peak in first-phase insulin secretion was attained 2 minutes after onset of release ( $t=15$ minutes) and measured $8.8 \pm 1.7 \mathrm{ng} / \mathrm{ml}(n=4)$. Insulin release then exhibited a transient nadir phase ( $t=18-21$ minutes) during which release rates averaged $4-5 \mathrm{ng} / \mathrm{ml}$, before accelerating again during second-phase insulin secretion to approximately 18 $\mathrm{ng} / \mathrm{ml}$ at $t=36$ minutes and later. When the same experiment was repeated in $\mathrm{Ca}_{V} 2.3^{-/-}$pancreata (Figure 4B), the peak in first-phase insulin secretion was only slightly reduced (19\%) and measured $7.1 \pm 2.1 \mathrm{ng} / \mathrm{ml}(\mathrm{NS} ; n=4)$. More importantly, second-phase insulin release was markedly suppressed and averaged $9.4 \pm 2.7 \mathrm{ng} / \mathrm{ml}$ at $t=40$ minutes, representing a $46 \%$ reduction compared with WT $(P<0.05)$.

Genetic ablation of Cav2.3 may result in compensatory mechanisms resulting in rearrangements of the $\mathrm{Ca}^{2+}$ channels in the $\beta$ cell itself or neighboring $\alpha$ and $\delta$ cells. In addition, we wanted to verify that the observed effects of $\mathrm{Ca}_{\mathrm{V}} 2.3$ on insulin secretion are not limited to the background C57B mouse strain. Similar experiments were therefore made in pancreata from standard inbred NMRI mice, but instead $\mathrm{Ca}_{\mathrm{V}} 2.3$ channel function was inhibited by SNX482. In the absence of the channel inhibitor, first-phase insulin secretion was initiated with a 2 -minute delay and peaked 1 minute, 30 seconds later when it measured $15.3 \pm 2.5 \mathrm{ng} / \mathrm{ml}(n=6)$.
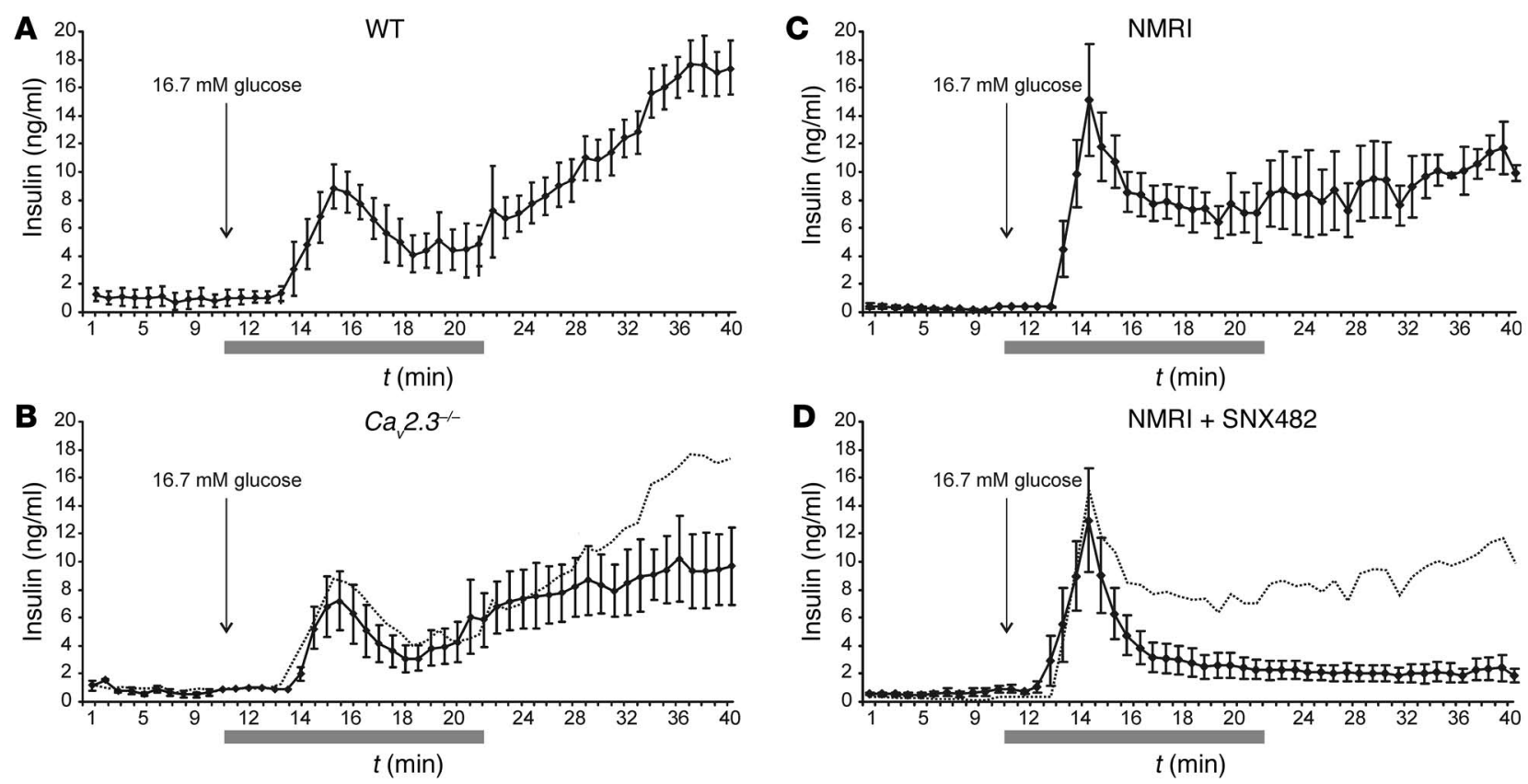

Figure 4

Dynamics of insulin release. (A) Insulin release measured in WT Cav2.3+/+ pancreata before and after increasing the glucose concentration in the perfusate from $3.3 \mathrm{mM}$ to $16.7 \mathrm{mM}$ at $t=11$ minutes. Samples were taken at 60 -second intervals, except during the first 10 minutes after increasing the glucose concentration ( $t=11$ to 21 minutes, as indicated by the gray bar) when the sample interval was 30 seconds. (B) Insulin release was measured as in $\mathbf{A}$, but the experiments were performed in Cav2.3 $3^{-1-}$ mice. To facilitate comparison with WT, mean values measured under that condition are indicated by the dotted line. Data in $\mathbf{A}$ and $\mathbf{B}$ represent means \pm SEM from 4 and 5 experiments in WT and Cav2.3 $3^{-/-}$mice, respectively. (C) Insulin release was measured as in A, but the experiments were performed in NMRI mice. (D) Insulin release was measured as in C, but SNX482 (100 nM) was included in the high-glucose solution. To facilitate comparison with mean values measured in the absence of SNX482, these values are denoted by the dotted line. Data in $\mathbf{C}$ and $\mathbf{D}$ represent means \pm SEM from 6 experiments performed with and without SNX482, respectively. Statistical significance is provided in Results. 
A

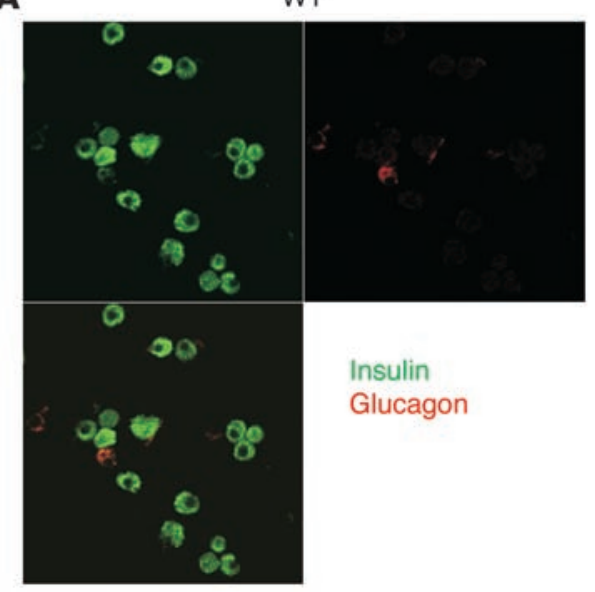

B

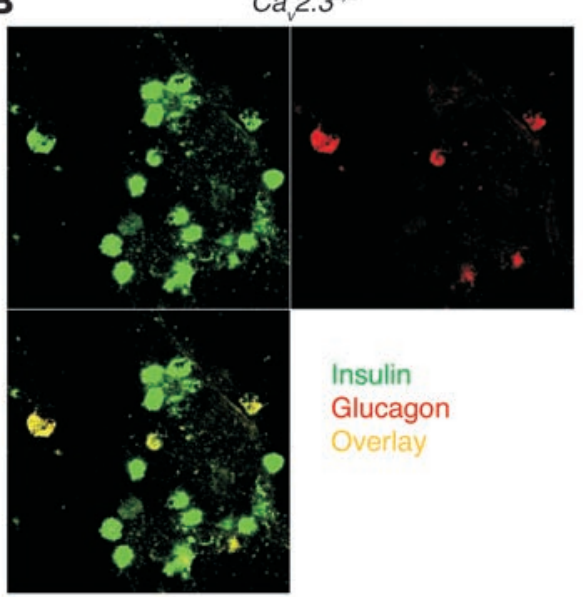

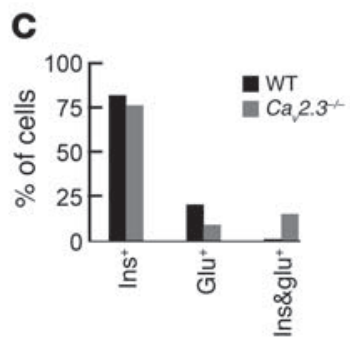

\section{Figure 5}

Confocal immunocytochemistry of insulin and glucagon immunoreactivity in single islet cells. (A) Insulin and glucagon immunoreactivity in dispersed WT islet cells visualized by confocal microscopy. (B) Insulin and glucagon immunoreactivity was visualized as in A, but cells are from

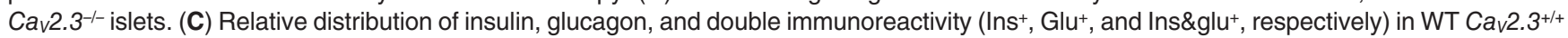
(black bars) and Cav2.3 $3^{-/}$(gray bars) islet cells. Data represent more than 200 cells in each group and are from 3 different experiments.

Insulin release then decayed toward a lower plateau level of approximately $8 \mathrm{ng} / \mathrm{ml}$ and increased slightly to approximately $10 \mathrm{ng} / \mathrm{ml}$ during the second phase (Figure 4C). When SNX482 (100 nM) was included in the perfusate (Figure 4D), first-phase insulin release was largely unaffected, and peak values averaged $13.0 \pm 3.7 \mathrm{ng} / \mathrm{ml}$ $(n=6)$. By contrast, second-phase insulin secretion was reduced more than $80 \%$ (e.g., $1.8 \pm 0.6 \mathrm{ng} / \mathrm{ml}$ versus $10.0 \pm 0.6 \mathrm{ng} / \mathrm{ml}$ at $t=40$ minutes in the presence or absence of SNX482, respectively; $P<0.01$ ). It was verified that the glucose concentration in the effluent medium was identical in all experiments.

Insulin and glucagon immunoreactivity in WT and $\mathrm{Ca}_{V} 2.3^{-1-}$ islet cells. Islet cells were finally dispersed and investigated by confocal immunocytochemistry (Figure 5). In WT islet cells, $80 \%$ of the dispersed cells revealed immunoreactivity for insulin and approximately $20 \%$ stained positive for glucagons in double-labeling experiments. The relative frequency of $\alpha$ and $\beta$ cells suggested by this analysis compares favorably with the electrophysiological data. Only 1 out of 230 cells investigated revealed immunoreactivity for both insulin and glucagons. A rather different picture emerged in the $C a_{V} 2.3^{-/-}$islet cell preparation. Whereas $75 \%$ and $9 \%$ of the cells could readily be characterized as $\beta$ and $\alpha$ cells, respectively, $16 \%$ of the 210 cells coexpressed insulin and glucagons.

\section{Discussion}

Insulin-producing $\beta$ cells contain multiple types of $\mathrm{Ca}^{2+}$ channel. Whereas the role of L-type $\mathrm{Ca}^{2+}$ channels in insulin secretion is amply documented, that of the non-L-type $\mathrm{Ca}^{2+}$ channels is less well understood. The advent of subtype-specific $\mathrm{Ca}^{2+}$ channel blockers in combination with the generation of transgenic knockout mice provides a unique opportunity for an in-depth analysis of the function(s) fulfilled by the different $\mathrm{Ca}^{2+}$ channel subtypes. Here we have used SNX482 and $\mathrm{Ca}_{\mathrm{V}} 2.3$-null mice to study the significance of R-type $\mathrm{Ca}_{\mathrm{v}} 2.3 \mathrm{Ca}^{2+}$ channels in islet insulin and glucagon secretion in vivo and in vitro.

The role of $C \mathrm{C}_{V} 2.3$ channels for $\beta$ cell $\left[\mathrm{Ca}^{2+}\right]_{i}$ homeostasis and insulin secretion. Here we demonstrate that pharmacological inhibition of R-type $\mathrm{Ca}_{\mathrm{V}} 2.3 \mathrm{Ca}^{2+}$ channels using SNX482 does not affect first-phase insulin secretion, but reduces second-phase release a dramatic $80 \%$. A similar preferential effect on late-phase insulin secretion is observed in $\mathrm{C} a_{V} 2.3^{-/-}$mice (Figure 4). At the single $\beta$ cell level, close inspection of the capacitance recordings (Figure 2, $\mathrm{A}$ and $\mathrm{B}$ ) reveals that the initial component of exocytosis is not much affected in $C a_{V} 2.3^{-/-} \beta$ cells. In fact, the overall reduction results exclusively from suppression of the late component of exocytosis (elicited by the third and subsequent depolarizations). We have previously demonstrated that opening of L-type Cav1.2 $\mathrm{Ca}^{2+}$ channels is tightly associated with rapid exocytosis and first-phase secretion. Thus, it appears that $\mathrm{Ca}^{2+}$ entry via L-type $\mathrm{Ca}_{V} 1.2$ and R-type Cav2.3 channels have distinct intracellular effects.

Cav 2.3 ablation is associated with a $23 \%$ decrease in $\beta$ cell $\mathrm{Ca}^{2+}$ current in $\mathrm{Ca}_{V} 2.3^{-/-}$mice (Figure 1). This is in good agreement with the response to acute application of SNX482 in WT mice (13), suggesting that there is little compensatory upregulation of other $\mathrm{Ca}^{2+}$ channels in the knockout mice. We acknowledge that Cav2.3 channel activity may represent only part of the R-type current component $(24,32)$. In addition, other reports suggest that all R-type current components are not blocked by SNX482 with the same efficacy (33). The observation that SNX482 fails to affect whole cell $\mathrm{Ca}^{2+}$ currents in $\mathrm{Ca}_{V} 2.3^{-/-} \beta$ cells (Figure 1, $\mathrm{C}$ and D), however, indicates at least that SNX482, at the concentration used here $(100 \mathrm{nM})$, does not affect any $\mathrm{Ca}^{2+}$ channels other than $\mathrm{Ca}_{\mathrm{V}} 2.3$, but we cannot exclude the contribution of an SNX482-insensitive R-type $\mathrm{Ca}^{2+}$ current component. Indeed, approximately $40 \%$ of the whole cell $\mathrm{Ca}^{2+}$ current is unaffected by either SNX482 or the L-type blocker isradipine in $\mathrm{Ca}_{V} 2.3^{-1-}$ $\beta$ cells. Although most of this current probably represents $\mathrm{P} / \mathrm{Q}$-type $\mathrm{Ca}^{2+}$ currents as previously shown for WT $\beta$ cells (13), it is possible that part of it reflects a SNX482-resistant portion of the R-type $\mathrm{Ca}^{2+}$ current.

How do $\mathrm{Ca}_{V} 2.3 \mathrm{Ca}^{2+}$ channels regulate second-phase insulin secretion? Secretory granules in pancreatic $\beta$ cells can be classified according to their release competence (34). A limited (1-5\%) pool is immediately available for rapid exocytosis upon stimulation (readily releasable pool, RRP). Once this pool of granules has been 
released, exocytosis proceeds at a slower rate determined by the supply of granules newly mobilized from a much larger reserve pool (35). The observation that only a late component of exocytosis is affected in $\mathrm{Ca}_{V} 2.3^{-/-} \beta$ cells (Figure 2, A and B) argues that $\mathrm{Ca}_{\mathrm{v}} 2.3$ channels are not tightly coupled to exocytosis but are more important for the recruitment of new granules for release. We also demonstrate that genetic ablation of the $\mathrm{Ca}_{\mathrm{V}} 2.3 \mathrm{Ca}^{2+}$ channels results in approximately $20 \%$ reduction of the glucose-induced steady-state time-averaged $\left[\mathrm{Ca}^{2+}\right]_{\mathrm{i}}$ (more than 5 minutes after initial response; Figure 3). Can these 2 pieces of information be reconciled? We have reported previously that a moderate (40\%) but protracted elevation of $\left[\mathrm{Ca}^{2+}\right]_{\mathrm{i}}$ results in strong enhancement of the exocytotic capacity (36). It is of interest that this effect is mediated by a global rather than a localized increase in $\left[\mathrm{Ca}^{2+}\right]_{\mathrm{i}}$ and is operational already at concentrations as low as $200-300 \mathrm{nM}$, that is, 10 -fold lower than those required to elicit fast exocytosis. Thus, even moderate reduction of $\mathrm{Ca}^{2+}$ entry and $\left[\mathrm{Ca}^{2+}\right]_{i}$ following inhibition of $\mathrm{Ca}_{\mathrm{V}} 2.3 \mathrm{Ca}^{2+}$ channels can have strong effects on insulin secretion in the longer term by inhibition of granule recruitment. Presumably, L-type $\mathrm{Ca}^{2+}$ channels still trigger granule exocytosis, but once the RRP is depleted, the supply of new granules for release becomes rate limiting. This would explain how ablation of the approximately $20 \% \mathrm{Ca}_{\mathrm{v}} 2.3 \mathrm{Ca}^{2+}$ channel component can result in approximately $50 \%$ (knockout) to $80 \%$ (SNX482) reduction of second-phase insulin secretion. Thus, it seems justifiable to conclude that $\mathrm{Ca}^{2+}$ entry via R-type $\mathrm{Ca}_{v} 2.3 \mathrm{Ca}^{2+}$ channels is functionally (and perhaps spatially) linked to granule mobilization and priming of insulin granules for release.

$C a_{V} 2.3$ ablation and glucagon secretion. $\mathrm{Ca}_{\mathrm{V}} 2.3$ ablation is associated with disturbances of glucagon secretion. In isolated islets, the ability of glucose to suppress glucagon secretion is severely impaired (Table 3). These abnormalities are also detectable at the systemic level. In the in vivo glucose challenge test, 3 -minute values for plasma glucagon were stimulated approximately $15 \%$ in Cav $2.3^{-/-}$mice, whereas in WT they were reduced approximately $20 \%$ (Table 1). The observations that whole cell $\mathrm{Ca}^{2+}$ currents (Figure 1, E and F) and single cell exocytosis (Figure 2, E-H) are unaffected in $\mathrm{Ca}_{V} 2.3^{-/-} \alpha$ cells, taken together with the finding that the R-type blocker SNX482 fails to affect glucagon release in WT islets (Table 2), make it unlikely that these effects are the direct consequence of the loss of $\mathrm{Ca}_{\mathrm{v}} 2.3$ in the $\alpha$ cell. Rather, the explanation for the perturbation of glucose-inhibited glucagon release in $\mathrm{Ca}_{\mathrm{v}} 2.3$-ablated mice appears to be due to the appearance of atypical $\alpha / \beta$ cells accounting for greater than $60 \%$ of the glucagon-expressing cells in these mice (Figure 5, $\mathrm{B}$ and $\mathrm{C})$. Taken together with the scarcity of cells with $\alpha$ cell electrophysiological properties in preparations from $\mathrm{Ca}_{V} 2.3^{-1-}$ mice ( $7 \%$ compared with $27 \%$ in WT mice), this suggests that the $\alpha / \beta$ cells electrical behavior is more like that of the $\beta$ cells. This idea is supported by the results in Table 3 , showing that whereas isradipine suppresses glucagon release in $\mathrm{Ca}_{V} 2.3^{-/-}$ islets, it has the opposite effect in WT islets. This observation also provides a clue to the relative failure of glucose to suppress glucagon release in $C a_{V} 2.3^{-/-}$islets both in vitro and (acutely) in vivo. The fact that glucagon eventually decreases after a glucose challenge in vivo may be related to neuronal input or paracrine effects that are known to be of great importance for the control of the hyperglycemic hormone (37). Surprisingly, basal glucagon release (at low glucose) is unaffected in $\mathrm{C} a_{V} 2.3^{-1-}$ islets. One possibility is that the reduced population of normal $\alpha$ cells have a very large capacity for exocytosis, but the capacitance measurements (Figure 2, E-H) provide no support for this notion. Another explanation is that the $\alpha / \beta$ cells exhibit poorly regulated exocytosis and constitutively release both glucagon and insulin. This idea is reinforced by the observation that basal insulin release in $\mathrm{C} a_{V} 2.3^{-/-}$islets is higher than in WT islets $(0.4 \pm 0.05$ versus $0.2 \pm 0.02 \mathrm{ng} /$ islet/hour in $C a_{V} 2.3^{-/-}$and WT, respectively; Table 3). Yet another possibility is that glucagon coreleased with insulin from the $\alpha / \beta$ cells potentiates further secretion by a cAMP-dependent mechanism. We have reported elsewhere that glucagon increases $\beta$ cell exocytosis 5 -fold (38). The significance of paracrine mechanisms within the islet is apparent from the strong stimulatory action of isradipine on glucagon secretion in WT islets (Tables 2 and 3). The latter effect may reflect the relief from paracrine inhibition of glucagon secretion exerted by $\mathrm{Zn}^{2+}$ and GABA cosecreted with insulin from the $\beta$ cells $(39,40)$. Preliminary data from our laboratory indicate that R-type $\mathrm{Ca}_{\mathrm{V}} 2.3 \mathrm{Ca}^{2+}$ channels play a decisive role in somatostatin secretion from the $\delta$ cells (Q. Zhang, A. Salehi, E. Renström, and P. Rorsman, unpublished observations). We can exclude that the loss of physiological glucose inhibition of glucagon secretion is secondary to relief from paracrine inhibition by somatostatin, however, since the dysregulation of glucagon secretion in CaV $2.3^{-1-}$ islets is not mimicked by SNX 482 .

Role of Cav2.3 in islet cell differentiation. A surprising finding in the present study is that the majority of the glucagon immunoreactive cells in $\mathrm{Ca}_{V} 2.3^{-/-}$islets coexpress insulin, indicating that $\mathrm{Ca}_{\mathrm{V}} 2.3$ channels play a role in the development of mature $\alpha$ cells. A transient peak in $\mathrm{Ca}_{\mathrm{V}} 2.3$ channel expression in glial cells along specific CNS pathways has been demonstrated to coincide with postnatal myelinization of the white matter in the rat (41). It can be speculated that $\mathrm{Ca}_{V} 2.3$ channel expression exerts a similar action in defining the differentiated mature islet cell lineages, but the exact underlying mechanism remains to be established.

Pathophysiological implications. Although R-type Cav2 2.3 channels appear to be of little importance for first-phase insulin secretion and their contribution becomes apparent only during late exocytosis/second-phase insulin secretion, this does not mean that they are unimportant for systemic glucose homeostasis. Indeed, the $\mathrm{Ca}_{V} 2.3^{-/-}$mice exhibited basal hyperglycemia (Table 1). In humans, $\mathrm{Ca}_{\mathrm{v}} 2.3$ is encoded by the CACNA1E gene, which is located on chromosome 1q25-31. Interestingly, a chromosomal region around $1 \mathrm{q} 25$ reveals linkage to type 2 diabetes in several independent studies in different populations. These include early onset type 2 diabetes in Pima Indians (42), Utah Caucasians (43), and English sib pairs (44). In addition, the 1q25-32 region demonstrates linkage with elevated blood glucose levels in the Framingham Heart Study (45). It is also pertinent that the above region confers defective insulin secretion in type 2 diabetes in Pima Indians (46). Type 2 diabetes is a multifactorial polygenic disorder. Clearly, polymorphisms in the CACNA1E gene alone are not sufficient to trigger disease. Given the present functional data, however, it is tempting to speculate that dysfunctional $\mathrm{Ca}_{v} 2.3 \mathrm{Ca}^{2+}$ channels may frequently be involved in creating the disturbed $\beta$ cell phenotype in type 2 diabetes.

\section{Methods}

Experimental animals. As previously reported (26), the CACNA1E gene encoding $\mathrm{Ca}_{\mathrm{v}} 2.3$ was disrupted in vivo by deleting a region containing exon 2 on mating $\mathrm{Ca}_{\mathrm{v}} 2.3^{\mathrm{fl} /+}$ and deleter mice on a C57Bl/ 6 background 
that expresses Cre recombinase constitutively under the control of the $\mathrm{CMV}$ promoter. $\mathrm{Ca}_{v} 2.3^{+/-}$mice containing 1 cre transgene were inbred, and pups with the $\mathrm{Ca}_{V} 2.3^{-/-}$genotype were selected and transferred by embryo transfer into a SPF facility. The transfer included breeding with $\mathrm{C} 57 \mathrm{Bl} / 6$ mice and resulted in heterozygous $\mathrm{Ca}_{v} 2.3^{+/-}$mice. Only cre-negative pups were selected and inbred, yielding either $\mathrm{Ca}_{V} 2.3^{+/+}$or $\mathrm{C} a_{V} 2.3^{-/-}$ mice. Thus, the $C a_{V} 2.3^{+/+}$and $C a_{V} 2.3^{-/-}$mice used in this study have an identical genetic background. In Figure 4, inbred NMRI mice purchased from Charles River Wiga GmbH were used.

The mice were housed at a constant temperature $\left(22-23^{\circ} \mathrm{C}\right)$ and 12 -hour light cycles (6:00 a.m.-6:00 p.m.), with access to standard pellet food and water ad libitum. All experiments were evaluated and approved by the local ethical committee Malmö/Lund djurförsöksetiska nämnd, Lund District Court, Sweden.

Islet isolation and islet cell preparation. The mice were sacrificed by cervical dislocation, and collagenase was administered into the pancreas by retrograde injection via the pancreatic duct. After 15-20 minutes' incubation at $37^{\circ} \mathrm{C}$, the islet suspension was washed 4 times with $\operatorname{HBSS}\left(4^{\circ} \mathrm{C}\right)$ before being manually collected. The islets were cultured in RPMI-1640 medium (Invitrogen Corp.) supplemented with 10\% FCS, penicillin, and streptomycin. For the preparation of single cells, islets obtained by collagenase digestion were dissociated by incubation and gentle triculation in $\mathrm{Ca}^{2+}$-free medium. The resulting cell suspension was centrifuged, the supernatant discarded, and the pellet (containing the cells) was resuspended in RPMI1640 medium, plated on plastic Nunc 35-mm Petri dishes, and maintained in tissue culture for up to 2 days.

Electrophysiology. The measurements were conducted using an EPC-10 patch-clamp amplifier in conjunction with the PULSE software suite (version 8.53; HEKA Elektronik). Whole-cell $\mathrm{Ca}^{2+}$ currents were measured in intact cells using the perforated-patch whole-cell approach (Figure 1) using a pipette solution consisting of $76 \mathrm{mM} \mathrm{Cs}_{2} \mathrm{SO}_{4}, 10 \mathrm{mM}$ $\mathrm{NaCl}, 10 \mathrm{mM} \mathrm{CsCl}, 1 \mathrm{mM} \mathrm{MgCl}_{2}, 5 \mathrm{mM}$ HEPES (pH 7.35 with $\mathrm{KOH}$ ), and $0.24 \mathrm{mg} / \mathrm{ml}$ amphotericin B (47). Exocytosis was monitored as increases in cell capacitance using the sine + DC mode of the lock-in amplifier included in the PULSE software and the standard whole cell configuration. When eliciting exocytosis by trains of ten 500-ms voltage clamp depolarizations (Figure 2, A and E), the pipette solution consisted of $125 \mathrm{mM}$ Cs-glutamate, $10 \mathrm{mM} \mathrm{CsCl}, 10 \mathrm{mM} \mathrm{NaCl}, 1 \mathrm{mM} \mathrm{MgCl}_{2}, 5 \mathrm{mM}$ HEPES, 3 mM Mg-ATP, 0.1 mM cAMP, and 0.05 mM EGTA (pH 7.2 with $\mathrm{CsOH}$ ). In Figure 2, C and G, this pipette solution was slightly modified to include $10 \mathrm{mM}$ EGTA and $9 \mathrm{mM} \mathrm{CaCl}_{2}$, and all $\mathrm{Cs}^{+}$salts were replaced by corresponding $\mathrm{K}^{+}$salts. The resulting free intracellular $\mathrm{Ca}^{2+}$ concentration of this $\mathrm{Ca}^{2+} /$ EGTA buffer was estimated to $1.5 \mu \mathrm{M}$ using the binding constants of Martell and Smith $(48,49)$. The extracellular bath solution contained $138 \mathrm{mM} \mathrm{NaCl}, 5.6 \mathrm{mM} \mathrm{KCl}, 2.6 \mathrm{mM} \mathrm{CaCl}_{2}, 1.2$ $\mathrm{mM} \mathrm{MgCl}_{2}, 5 \mathrm{mM}$ glucose, and $5 \mathrm{mM}$ HEPES (pH 7.4 with $\mathrm{NaOH}$ ). In the recordings of whole-cell $\mathrm{Ca}^{2+}$ currents (Figure 1) and depolarizationevoked exocytosis (Figure 2, A and E), $20 \mathrm{mM}$ of $\mathrm{NaCl}$ was equimolarly replaced by the $\mathrm{K}^{+}$channel blocker TEA-Cl to facilitate the separation of the small voltage-gated $\mathrm{Ca}^{2+}$ currents from the large outward $\mathrm{K}^{+}$current. The DHP isradipine (Pfizer Inc.) was prepared as stock solution in DMSO (final concentration less than or equal to $0.1 \%$ ). The R-type blocker SNX482 (Peptide Institute Inc.) was dissolved directly in the extracellular medium. All other reagents were from Sigma-Aldrich. Effects were determined in the steady state. The bath (approximately $1.5 \mathrm{ml}$ ) was continuously perfused $(6 \mathrm{ml} / \mathrm{min})$ and the temperature maintained at approximately $32^{\circ} \mathrm{C}$.

In vivo glucose challenges. For the in vivo studies, glucose $(11.1 \mathrm{mmol}$ [equivalent to $2 \mathrm{~g}$ ] $/ \mathrm{kg}$ body weight) was dissolved in $0.9 \% \mathrm{NaCl}$ and delivered by intraperitoneal injection. Blood sampling, detection of plasma insulin by RIA, and enzymatic determination of plasma glucose concentrations were performed as described previously (50).

In situ/ex vivo pancreatic perfusion. Experiments were performed in the morning at 10:00 a.m. in nonfasted mice. Anesthesia was given by intraperitoneal injection of midazolam (Hofmann-La Roche AG; $0.4 \mathrm{mg} /$ 25 g body weight) and fentanyl (Janssen Pharmaceuticals Inc.; $0.02 \mathrm{mg} /$ 25 g body weight). The experimental procedures were essentially identical to those described by Bonnevie-Nielsen et al. (51). Briefly, the mice were kept on a heating pad during the entire experiment. After opening the abdominal cavity and ligating the renal, hepatic, and splenic arteries, the aorta was tied off above the level of the pancreatic artery. The pancreas was perfused with modified Krebs-Ringer HEPES buffer preheated to $37^{\circ} \mathrm{C}$ $(1 \mathrm{ml} / \mathrm{min})$ via a silicone catheter placed in the aorta. The perfusate was collected via a silicone catheter from the portal vein at 30- or 60-second intervals, as indicated, in 2.5-ml Eppendorf tubes containing $25 \mu \mathrm{l}$ Trasylol. Insulin and glucose concentrations in the effluent medium were detected by RIA and the glucose oxidase method, respectively.

In vitro pancreatic hormone release. Insulin release in vitro was measured in static incubations. Briefly, freshly isolated islets were preincubated for 30 minutes at $37^{\circ} \mathrm{C}$ in a Krebs-Ringer bicarbonate buffer ( $\mathrm{pH}$ 7.4) consisting of $120 \mathrm{mM} \mathrm{NaCl}, 25 \mathrm{mM} \mathrm{NaHCO}_{3}, 4.7 \mathrm{mM} \mathrm{KCl}, 1.2 \mathrm{mM} \mathrm{MgSO}_{4}$, $2.5 \mathrm{mM} \mathrm{CaCl}_{2}, 1.2 \mathrm{mM} \mathrm{KH}_{2} \mathrm{PO}, 1 \mathrm{mM}$ glucose, and $10 \mathrm{mM}$ HEPES ( $\mathrm{pH}$ 7.4). The medium was gassed with $95 \% \mathrm{O}_{2}$ and $5 \% \mathrm{CO}_{2}$ to obtain constant $\mathrm{pH}$ and oxygenation. Groups of 10 islets were then incubated in $1 \mathrm{ml}$ for 60 minutes at $37^{\circ} \mathrm{C}$ in Krebs-Ringer buffered solution supplemented with either glucose, the L-type $\mathrm{Ca}^{2+}$ channel blocker isradipine, the R-type $\mathrm{Ca}^{2+}$ channel inhibitor SNX482, tolbutamide, or high $\mathrm{K}^{+}$, as specified in the text and figures. Immediately after incubation, a $25-\mu 1$ aliquot of the medium was removed for assay of insulin and glucagon radioimmunoassay as described previously (50).

Immunocytochemistry. Insulin and glucagon immunoreactivities were visualized in dissociated islet cells by indirect immunocytochemistry using a Carl Zeiss AG 510 LSM confocal microscope and a $\times 100$ Plan-Apochromat $\times 100 / 1.4$ oil objective. After fixation with $3 \%$ paraformaldehyde and permeabilization by $0.1 \%$ Triton-X, the cells were incubated with normal donkey serum to reduce unspecific staining. The primary insulin and glucagon Abs, raised in guinea pigs and sheep, respectively, were incubated at 1:1,000. To prevent cross-talk between the channels, the secondary Cy3-conjugated anti-guinea pig and the Cy5-conjugated anti-sheep Abs (1:600) were excited in the multitrack mode using the 543-nm and 633-nm lines of the HeNe lasers, and emitted light was collected using greater than $560-\mathrm{nm}$ and greater than 650-nm long-pass filters, respectively.

Microfluorimetry. $\left[\mathrm{Ca}^{2+}\right]_{\mathrm{i}}$ in intact pancreatic islets was measured by dual-wavelength microfluorimetry using fura-2 and a D104 PTI microfluorimetry system. The temperature of the experimental chamber was $+32^{\circ} \mathrm{C}$ to allow comparison with the electrophysiological data. Procedures for loading and calibration of the fluorescence signal were as described previously (52).

Statistical analysis. All data are given as means \pm SEM. Statistical significance was evaluated using absolute values only. A paired Student's $t$ test was used when comparing responses in the same cell. For comparisons between groups with independent observations we used independent Student's $t$ tests or, when comparisons involved more than 2 groups, ANOVA.

\section{Acknowledgments}

We thank Kristina Borglid and Britt-Marie Nilsson for expert technical assistance. This work was supported by the Swedish Research Council (grant numbers 13509, 12239, and 6589), the European Foundation for the Study of Diabetes, European 
Community network grant "Neuronal $\mathrm{Ca}^{2+}$ Channels," the Albert Påhlsson Foundation, the NovoNordisk Foundation, the Center of Molecular Medicine Cologne (BMBF $01 \mathrm{KS}$ 9502), and the Deutsche Forschungsgemeinschaft (SCH 387/9-1). P. Rorsman is a recipient of the Göran Gustafsson Award for Research in the Natural Sciences and Medicine.

1. Catterall, W.A. 1998. Structure and function of neuronal $\mathrm{Ca} 2+$ channels and their role in neurotransmitter release. Cell Calcium. 24:307-323.

2. D’Ascenzo, M., et al. 2004. Electrophysiological and molecular evidence of L-(Cav1), N- (Cav2.2), and $\mathrm{R}$ - (Cav2.3) type Ca2+ channels in rat cortical astrocytes. Glia. 45:354-363.

3. Dolphin, A.C. 1999. L-type calcium channel modulation. Adv. Second Messenger Phosphoprotein Res. 33:153-177.

4. Catterall, W.A. 2000. Structure and regulation of voltage-gated Ca2+ channels. Annu. Rev. Cell Dev. Biol. 16:521-555.

5. Reid, C.A., Bekkers, J.M., and Clements, J.D. 2003. Presynaptic Ca2+ channels: a functional patchwork. Trends Neurosci. 26:683-687.

6. Perez-Reyes, E. 2003. Molecular physiology of lowvoltage-activated T-type calcium channels. Physiol. Rev. 83:117-161.

7. Heady, T.N., Gomora, J.C., Macdonald, T.L., and Perez-Reyes, E. 2001. Molecular pharmacology of T-type Ca2+ channels. Jpn. J. Pharmacol. 85:339-350.

8. Triggle, D.J. 1998. The physiological and pharmacological significance of cardiovascular T-type, voltage-gated calcium channels. Am. J. Hypertens. 11:80S-87S.

9. Ashcroft, F.M., Proks, P., Smith, P.A., Ämmälä, C., Bokvist, K., and Rorsman, P. 1994. Stimulus-secretion coupling in pancreatic $\beta$ cells. J. Cell. Biochem. 55(Suppl.):54-65.

10. Del Prato, S., Marchetti, P., and Bonadonna, R.C. 2002. Phasic insulin release and metabolic regulation in type 2 diabetes. Diabetes. 51(Suppl. 1):S109-S116.

11. Grodsky, G.M., and Bolaffi, J.L. 1992. Desensitization of the insulin-secreting $\beta$ cell. J. Cell. Biochem. 48:3-11.

12. Henquin, J.C., Ravier, M.A., Nenquin, M., Jonas, J.C., and Gilon, P. 2003. Hierarchy of the $\beta$ cell signals controlling insulin secretion. Eur. J. Clin. Invest. 33:742-750.

13. Schulla, V., et al. 2003. Impaired insulin secretion and glucose tolerance in $\beta$ cell-selective $\mathrm{Ca}(\mathrm{v}) 1.2$ Ca2+ channel null mice. EMBO J. 22:3844-3854.

14. Sinnegger-Brauns, M.J., et al. 2004. Isoform-specific regulation of mood behavior and pancreatic $\beta$ cell and cardiovascular function by L-type $\mathrm{Ca}^{2+}$ channels. J. Clin. Invest. 113:1430-1439. doi:10.1172/ JCI200420208.

15. Wiser, O., et al. 1999. The voltage sensitive Lc-type $\mathrm{Ca} 2+$ channel is functionally coupled to the exocytotic machinery. Proc. Natl. Acad. Sci. U. S. A. 96:248-253.

16. Barg, S., Eliasson, L., Renström, E., and Rorsman, P. 2002. A subset of 50 secretory granules in close contact with L-type Ca2+ channels accounts for firstphase insulin secretion in mouse $\beta$ cells. Diabetes. 51(Suppl. 1):S74-S82.

17. Barg, S., et al. 2001. Fast exocytosis with few $\mathrm{Ca}(2+)$ channels in insulin-secreting mouse pancreatic B cells. Biophys. J. 81:3308-3323.

18. Mochida, S., et al. 2003. Requirement for the synaptic protein interaction site for reconstitution of synaptic transmission by P/Q-type calcium channels. Proc. Natl. Acad. Sci. U. S. A. 100:2819-2824.

19. Mochida, S., Sheng, Z.H., Baker, C., Kobayashi, H., and Catterall, W.A. 1996. Inhibition of neuro-
Received for publication June 24, 2004, and accepted in revised form October 24, 2004.

Address correspondence to: Erik Renström, Department of Physiological Sciences, BMC B11, SE-221 84 Lund, Sweden. Phone: 46-46222-06-39; Fax: 46-46-222-77-63; E-mail: erik.renstrom@mphy.lu.se. transmission by peptides containing the synaptic protein interaction site of $\mathrm{N}$-type $\mathrm{Ca} 2+$ channels. Neuron. 17:781-788.

20. Wu, L.G., Borst, J.G., and Sakmann, B. 1998 R-type Ca2+ currents evoke transmitter release at a rat central synapse. Proc. Natl. Acad. Sci. U. S. A. 95:4720-4725.

21. Dietrich, D., et al. 2003. Functional specialization of presynaptic Cav2.3 Ca2+ channels. Neuron. 39:483-496.

22. Saegusa, H., et al. 2000. Altered pain responses in mice lacking $\alpha 1 \mathrm{E}$ subunit of the voltage-dependent Ca2+ channel. Proc. Natl. Acad. Sci. U. S. A. 97:6132-6137.

23. Kubota, M., et al. 2001. Intact LTP and fear memory but impaired spatial memory in mice lacking $\mathrm{Ca}(\mathrm{v}) 2.3(\alpha(\mathrm{IE}))$ channel. Biochem. Biophys. Res. Commun. 282:242-248.

24. Lee, S.C., et al. 2002. Molecular basis of R-type calcium channels in central amygdala neurons of the mouse. Proc. Natl. Acad. Sci. U. S. A. 99:3276-3281.

25. Vajna, R., et al. 1998. New isoform of the neuronal $\mathrm{Ca} 2+$ channel $\alpha 1 \mathrm{E}$ subunit in islets of Langerhans and kidney-distribution of voltage-gated $\mathrm{Ca} 2+$ channel $\alpha 1$ subunits in cell lines and tissues. Eur. J. Biochem. 257:274-285.

26. Pereverzev, A., et al. 2002. Disturbances in glucose-tolerance, insulin-release, and stress-induced hyperglycemia upon disruption of the $\mathrm{Ca}(\mathrm{v}) 2.3$ $(\alpha 1 \mathrm{E})$ subunit of voltage-gated $\mathrm{Ca}(2+)$ channels. Mol. Endocrinol. 16:884-895.

27. Barg, S., Galvanovskis, J., Göpel, S.O., Rorsman, P., and Eliasson, L. 2000. Tight coupling between electrical activity and exocytosis in mouse glucagonsecreting $\alpha$ cells. Diabetes. 49:1500-1510.

28. Rutter, G.A., Theler, J.M., Li, G., and Wollheim, C.B. 1994. Ca2+ stores in insulin-secreting cells: lack of effect of cADP ribose. Cell Calcium. 16:71-80.

29. Bokvist, K., Eliasson, L., Ämmälä, C., Renström, E., and Rorsman, P. 1995. Co-localization of L-type $\mathrm{Ca} 2+$ channels and insulin-containing secretory granules and its significance for the initiation of exocytosis in mouse pancreatic B cells. EMBO J. 14:50-57.

30. Nadal, A., Quesada, I., and Soria, B. 1999. Homologous and heterologous asynchronicity between identified $\alpha$-, $\beta$ - and delta cells within intact islets of Langerhans in the mouse. J. Physiol. 517:85-93.

31. Satin, L.S. 2000. Localized calcium influx in pancreatic $\beta$ cells: its significance for $\mathrm{Ca} 2+$-dependent insulin secretion from the islets of Langerhans. Endocrine. 13:251-262.

32. Wilson, S.M., et al. 2000. The status of voltagedependent calcium channels in $\alpha 1 \mathrm{E}$ knock-out mice. J. Neurosci. 20:8566-8571.

33. Tottene, A., Volsen, S., and Pietrobon, D. 2000. $\alpha(1 \mathrm{E})$ subunits form the pore of three cerebellar R-type calcium channels with different pharmacological and permeation properties. J. Neurosci. 20:171-178.

34. Neher, E. 1998. Vesicle pools and Ca2+ microdomains: new tools for understanding their roles in neurotransmitter release. Neuron. 20:389-399.

35. Rorsman, P., and Renström, E. 2003. Insulin granule dynamics in pancreatic $\beta$ cells. Diabetologia. 46:1029-1045

36. Gromada, J., et al. 1999. CaM kinase II-dependent mobilization of secretory granules underlies acetylcholine-induced stimulation of exocytosis in mouse pancreatic B cells. J. Physiol. 518:745-759.

37. Nandi, J., et al. 2002. Central mechanisms involved with catabolism. Curr. Opin. Clin. Nutr. Metab. Care. 5:407-418.

38. Gromada, J., Ding, W.G., Barg, S., Renström, E., and Rorsman, P. 1997. Multisite regulation of insulin secretion by CAMP-increasing agonists: evidence that glucagon-like peptide 1 and glucagon act via distinct receptors. Pflugers Arch. 434:515-524.

39. Ishihara, H., Maechler, P., Gjinovci, A., Herrera, P.L., and Wollheim, C.B. 2003. Islet $\beta$ cell secretion determines glucagon release from neighbouring $\alpha$ cells. Nat. Cell Biol. 5:330-335.

40. Wendt, A., et al. 2004. Glucose inhibition of glucagon secretion from rat $\alpha$ cells is mediated by GABA released from neighboring $\beta$ cells. Diabetes. 53:1038-1045.

41. Chen, S., Ren, Y.Q., Bing, R., and Hillman, D.E. 2000. A 1E subunit of the R-type calcium channel is associated with myelinogenesis. J. Neurocytol. 29:719-728.

42. Hanson, R.L., et al. 1998. An autosomal genomic scan for loci linked to type II diabetes mellitus and body-mass index in Pima Indians. Am. J. Hum. Genet. 63:1130-1138.

43. Elbein, S.C., Hoffman, M.D., Teng, K., Leppert, M.F., and Hasstedt, S.J. 1999. A genome-wide search for type 2 diabetes susceptibility genes in Utah Caucasians. Diabetes. 48:1175-1182.

44. Wiltshire, S., et al. 2001. A genomewide scan for loci predisposing to type 2 diabetes in a U.K. population (the Diabetes UK Warren 2 Repository): analysis of 573 pedigrees provides independent replication of a susceptibility locus on chromosome 1q. Am. J. Hum. Genet. 69:553-569.

45. Jun, G., Song, Y., Stein, C.M., and Iyengar, S.K. 2003. An autosome-wide search using longitudinal data for loci linked to type 2 diabetes progression. BMC Genet. 4(Suppl. 1):S8.

46. Hanson, R.L., et al. 2001. Family and genetic studies of indices of insulin sensitivity and insulin secretion in Pima Indians. Diabetes Metab. Res. Rev. 17:296-303.

47. Renström, E., Eliasson, L., Bokvist, K., and Rorsman, P. 1996. Cooling inhibits exocytosis in single mouse pancreatic $B$ cells by suppression of granule mobilization. J. Physiol. 494:41-52.

48. Martell, A.E., and Smith, R.M. 1971. Amino acids. Volume 1 of Critical stability constants. Plenum Press. New York, New York, USA.

49. Martell, A.E., and Smith, R.M. 1971. Amines. Volume 2 of Critical stability constants. Plenum Press. New York, New York, USA

50. Salehi, A., et al. 1999. Dysfunction of the islet lysosomal system conveys impairment of glucoseinduced insulin release in the diabetic GK rat. Endocrinology. 140:3045-3053.

51. Bonnevie-Nielsen, V., Steffes, M.W., and Lernmark, A. 1981. A major loss in islet mass and B cell function precedes hyperglycemia in mice given multiple low doses of streptozotocin. Diabetes. 30:424-429.

52. Olofsson, C.S., et al. 2002. Fast insulin secretion reflects exocytosis of docked granules in mouse pancreatic B cells. Pflugers Arch. 444:43-51. 